\title{
Primary chylopericardium: A case report and literature review
}

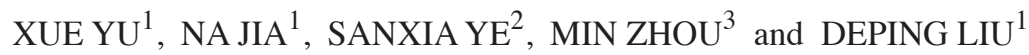 \\ ${ }^{1}$ Department of Cardiology, Beijing Hospital, National Center of Gerontology, Beijing 100730; ${ }^{2}$ Department of Internal \\ Medicine, Beijing Shijitan Hospital, Beijing 100038; ${ }^{3}$ Department of Cardiology, The First People's Hospital \\ of Changzhou, Changzhou, Jiangsu 213003, P.R. China
}

Received March 3, 2017; Accepted June 29, 2017

DOI: $10.3892 /$ etm.2017.5383

\begin{abstract}
Primary chylopericardium (CP) is a rare clinical condition in which chylous fluid containing high concentrations of triglyceride accumulates in the pericardial cavity. The present study reports a case of CP that was successfully treated by reconstruction surgery of thoracic duct. To improve the ability to diagnosis and treat this rare disease, the current study also systematically extracted 104 reported cases of primary or idiopathic CP from the past 60 years (January 1950 to December of 2015), and reviewed the clinical manifestation, etiology, diagnosis and treatment of these cases. The age at diagnosis varied between 6 weeks and 79 years with a mean age of $27.95 \pm 16.50$ years. Asymptomatic patients accounted for $39.42 \%$ of cases, while the most common initial symptoms were dyspnea (44.23\%) and coughing (10.58\%). Jugular venous distention and distant heart sound was identified in $23(22.12 \%)$ and 34 cases $(32.69 \%)$, respectively. Cardiomegaly in X-ray scans was detected in the majority of patients (93.27\%). In addition, lymphoscintigraphy and lymphangiography were helpful in identifying the source of chyle. Regarding the etiology, idiopathic cases accounted for $35.56 \%$ of the included cases in the present study. The most important cause of primary CP was abnormal connection or accumulation of lymph fluid in the pericardium (37.50\%). Conservative therapy included low-fat or medium-chain triglyceride diet, as well as total parenteral nutrition. The majority of patients $(71.2 \%)$ required surgery for definitive therapy, and thoracic duct ligation was the most preferred surgical procedure, performed in $44.23 \%$ of cases. Follow-up was reported in 64 cases, and all patients survived during the mean follow-up period of 12 months. Therefore, it is suggested that surgical management is the most successful treatment method and is associated with a favorable prognosis.
\end{abstract}

Correspondence to: Professor Deping Liu, Department of Cardiology, Beijing Hospital, National Center of Gerontology, 1 Dahua Road, Beijing 100730, P.R. China

E-mail: 1liudeping@263.net

Key words: primary chylopericardium, idiopathic chylopericardium, lymphatic malformation, review

\section{Introduction}

Idiopathic chylopericardium (CP) is a rare clinical entity that was first reported by Hasebroek in 1888 (1). The term primary CP was initially used in a study by Groves and Effler in 1954 (2), which described a case of isolated accumulation of chyle in the pericardium without any evident cause. Secondary CP typically refers to complications due to cardiothoracic surgery, trauma or a thrombus in the jugular vein, infection, radiotherapy, mediastinal tumors, hygromas, bone lymphangiomas, lymphoma, acute necrotic pancreatitis and other malignancies (3-5). Dib et al (6) analyzed the CP cases reported in the literature between 1996 and 2006, and observed that the idiopathic cause of CP accounted for $56 \%$ of cases. The possible mechanisms of idiopathic CP include the following: i) Impaired lymphatic valves on branches that are connected to the thoracic duct and pericardium lymphatic vessel; ii) elevated pressure in the thoracic duct that may occur in lymphangiectasia; iii) abnormal communication of lymphatic vessels to the pericardial lymphatics resulting in chylous reflux; and iv) congenital malformation.

Generalized lymphatic anomaly (GLA) is a rare congenital disease resulting in malformation of lymphatic vessels. GLA is known by multiple terms, including lymphangiomatosis, generalized lymphangioma, systemic cystic angiomatosis, multiple lymphangiectasia and generalized lymphatic malformation $(7,8)$. Lymphatic anomalies are considered to arise from disordered lymphatic development resulting in the proliferation of lymphatic channels (8). Lymphatic anomalies can also cause chylopericardium (CP), which is very rare. In the present case, lymphatic abnormality was confirmed by lymphangiography and surgery.

The present study reports a case of $\mathrm{CP}$ in an Asian male patient, who presented with no specific symptoms and with occasional detection of pericardial effusion by ultrasound. Furthermore, a literature review was performed to improve the understanding on the diagnosis and treatment of primary CP.

\section{Case report}

In June 2008, a 57-year-old man was admitted to the Cardiology Care Unit of Beijing Hospital (Beijing, China) with symptoms of dyspnea and chronic cough that persisted for 10 months. The patient did not present fever or chills 
at home. Workup examination included transthoracic echocardiography, which was performed 2 months prior to this admission, which demonstrated a large cardiac effusion. Upon physical examination on admission, the blood pressure was $135 / 80 \mathrm{mmHg}$ and the pulse was at $95 \mathrm{bpm}$. The patient was alert and oriented, and a neck exam did not detect jugular venous distention (JVD). The lungs were clear upon bilateral auscultation, without wheezing or crackles. Cardiovascular examination demonstrated a regular heart rhythm without murmurs, and the heart sound was distant. His abdomen was soft and non-tender on palpation, and the patient did not present hepatosplenomegaly. A chest X-ray scan demonstrated an enlarged cardiac silhouette, as shown in Fig. 1. Transthoracic echocardiography was repeated and demonstrated a large cardiac effusion with 6-34 mm of fluid in the apex and basal area (Fig. 2). Laboratory testing revealed an erythrocyte sedimentation rate of $12 \mathrm{~mm} / \mathrm{h}$ (normal range, $<15 \mathrm{~mm} / \mathrm{h}$ ). A purified protein derivative skin test was negative.

To alleviate the symptom of dyspnea and clarify the reason for it, the patient underwent diagnostic and therapeutic pericardiocentesis with the removal of $3,080 \mathrm{ml}$ milky fluid with symptomatic relief (Fig. 3). The pericardial effusion was confirmed to be chylous with the following contents: Specific gravity $\geq 1.030$; red blood cell count, $2,880 / \mathrm{mm}^{3}$; white blood cell count, $350 / \mathrm{mm}^{3}$; monocytes, $90 \%$; neutrophils, $10 \%$; glucose, $7 \mathrm{mmol} / \mathrm{l}$; total protein, $82 \mathrm{~g} / \mathrm{l}$; albumin, $27 \mathrm{~g} / \mathrm{l}$; lactate dehydrogenase, $150 \mathrm{U} / \mathrm{l}$; triglycerides (TG), $13.4 \mathrm{mmol} / \mathrm{l}$; total cholesterol (TC), $3.4 \mathrm{mmol} / \mathrm{l}$. The pericardial effusion was negative for tuberculosis via polymerase chain reaction analysis, while bacterial culture was also negative. Lymphangioscintigraphy with $99 \mathrm{mTc}-\mathrm{DX}$ demonstrated obstruction of the upper part of the thoracic duct and abnormal accumulation of radiotracer was observed in the pericardium after $3 \mathrm{~h}$ of injection (Fig. 4).

The patient was subsequently transferred to the Beijing Shijitan Hospital (Beijing,China) for surgery.Lymphangiography was conducted prior to surgery, which revealed four lymphatic collaterals below the left sternoclavicular joint divided from the thoracic duct. These collaterals communicated with the left supraclavicular vein, cervical lymph nodes and right supraclavicular vessel. Certain other communicating braches from the thoracic duct were connected with the left bronchomediastinal trunks abutting the pericardial sac. Chylous regurgitation was observed from the thoracic duct toward the left bronchomediastinal trunks. The patient was identified to have congenital anomalies of the thoracic duct. The end of thoracic duct was not converged to the left subclavian vein as usual, but branched with multiple small vessels and connected with other lymphatic vessels. Thus, the patient underwent thoracic duct-left internal jugular vein anastomosis and ligation of communicating branches between the thoracic duct and left bronchomediastinal trucks.

At 1 month after surgery, follow-up echocardiography revealed recurrence of a pericardial effusion. The patient underwent further pericardiocentesis with removal of $200 \mathrm{ml}$ chylous fluid, and conservative treatment including low-fat diet and medium-chain triglyceride (MCT) diet was continued from last admission. The patient responded well to treatment and presented a good quality of life without dyspnea on exertion upon follow-up at 6 months and 7 years.

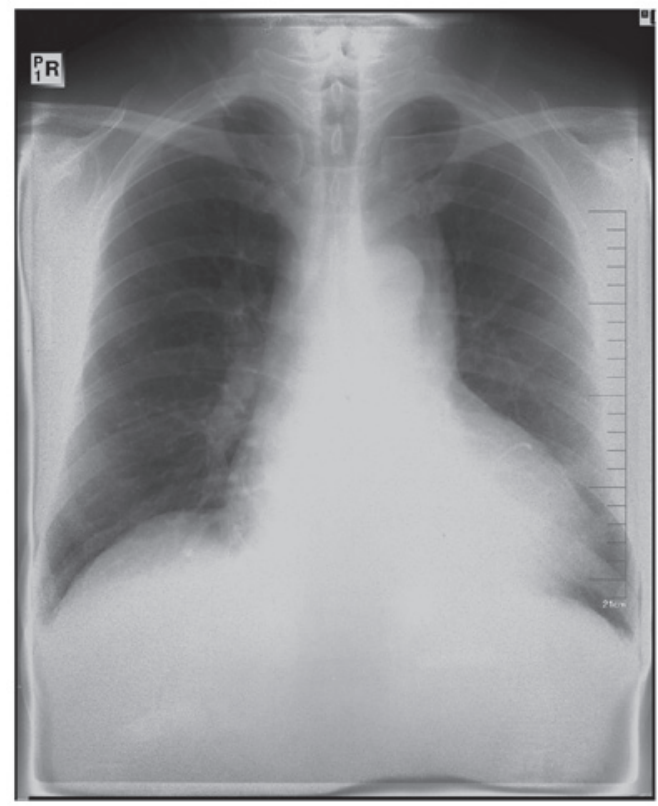

Figure 1. Chest X-ray scan demonstrated cardiomegaly with normal pulmonary vasculature.

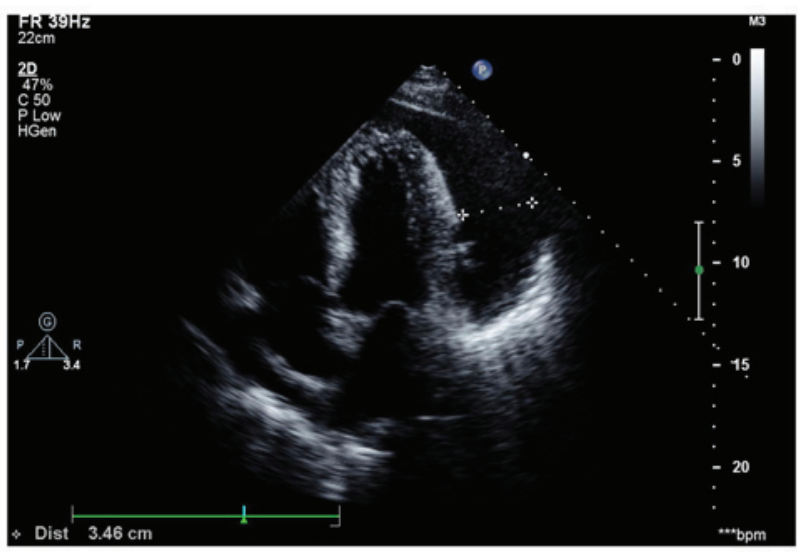

Figure 2. Apical four-chamber view on echocardiography demonstrated large pericardial effusion (depth, $3.46 \mathrm{~cm}$ ).

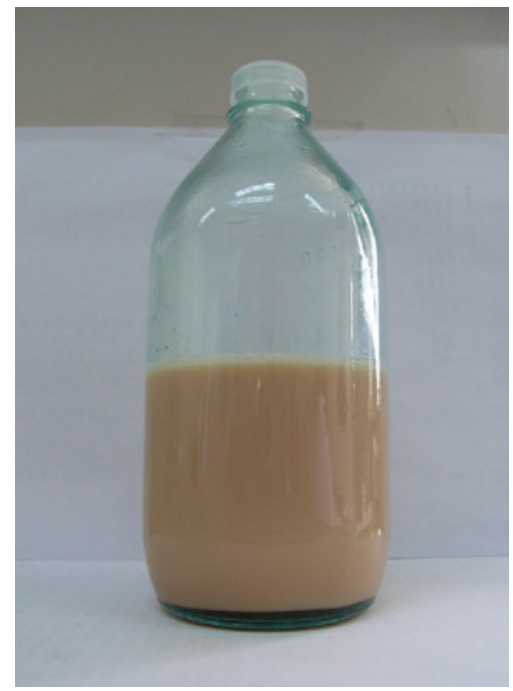

Figure 3. Pink milky pericardial effusion obtained through drainage during pericardiocentesis 


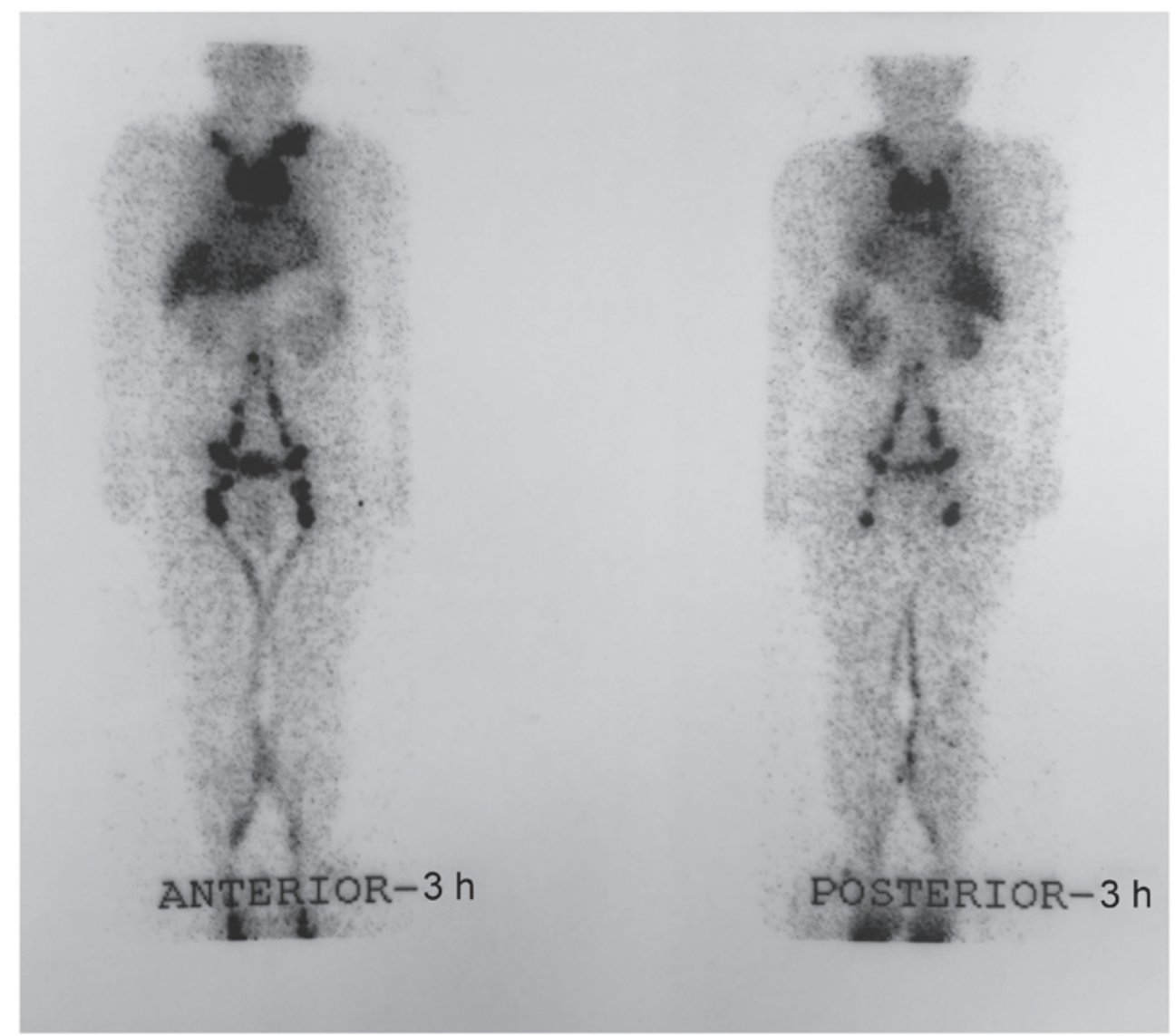

Figure 4. Lymphoscintigraphy revealing the obstruction of the upper thoracic duct, and abnormal accumulation of radiotracer was observed in the pericardium after $3 \mathrm{~h}$ of injection.

\section{Discussion}

The pericardial space usually contains $25-35 \mathrm{ml}$ of fluid, which is identical to lymph and is produced by the epicardium (9). The pericardium itself does not produce a large amount of fluid. Lymphatic vessels of the heart drain the pericardial fluid into the left subclavian vein via the mediastinal lymph vessels, lymph nodes and the thoracic duct (10). The main lymphatic flow from the pleura, the lower portion of the left lung, and the entire right lung and pericardium meet at the bronchomediastinal lymphatics $(11,12)$. Therefore, lymphatic flow regurgitation can occur simultaneously in multiple sites in the thoracic cavity, such as the pleura, lungs and pericardium. Obstruction of the upper area of the thoracic duct may then cause CP, pulmonary lymphedema and chylothorax. Furthermore, the intestinal lymph will be affected by the obstruction and result in chylous ascites.

Primary CP is a rare clinical entity in which chylous fluid containing high concentrations of TG accumulate in the pericardial cavity. Causes of CP include congenital mediastinal lymphangiectasia, iatrogenic development following cardiac surgery, malignant tumors, blunt or penetrating trauma, infection and congenital lymphatic anomalies (6,11,13-15). It has been reported that $\sim 56 \%$ of cases are idiopathic (6), and only $\sim 100 \mathrm{CP}$ cases have been reported worldwide (16). In the present study, a systematic review of the literature was performed to analyze the etiology, symptoms, physical examination features, laboratory findings, imaging, type of surgery and follow-up data of primary $\mathrm{CP}$ cases. A relatively large number of cases reported within the past 60 years were included in this systematic review. The current study aimed to provide further evidence for the recognition of primary $\mathrm{CP}$.

A systematic PubMed (www.ncbi.nlm.nih.gov/pubmed) and Wanfang (www.wanfangdata.com.cn) database search was conducted in order to identify English and Chinese studies describing primary or idiopathic CP reported between January 1, 1950 and December 31, 2015. The search terms included the following: 'primary chylopericardium' or 'idiopathic chylopericardium'. The bibliographies of all articles were subsequently independently reviewed by two of the authors. A total of 104 cases were identified from 92 studies (2-5,7,11-87). Patient demographics, clinical presentation, diagnosis and treatment were analyzed. Patients lacking laboratory data (such as the TG concentration), imaging or surgical findings that supported their primary or idiopathic $\mathrm{CP}$ definitive diagnosis were excluded from the present study. The mean \pm standard deviation was used to express count variables, which were statistically analyzed by SPSS version 20 (IBM Corp., Armonk, NY, USA).

According to the literature review conducted in the present study, 53 male $(50.96 \%)$ and 51 female $(49.03 \%)$ CP patients were identified. The age at diagnosis ranged between 6 weeks and 79 years, with a mean $27.95 \pm 16.50$ years, while 5 cases were $<3$ years old. The time from onset of symptoms to the diagnosis demonstrated a wide variation, ranging between a few hours and several years. 
The clinical manifestations, physical examination features, electrocardiogram and X-ray finding are listed in Table I. Dyspnea was the most common initial presenting symptom, followed by coughing. Other symptoms included palpitation, chest pain, gastrointestinal (GI) symptoms, syncope, fatigue and edema. In addition, cardiac tamponade occurred in certain patients as a result of decreased cardiac output due to their chronic pericardial effusion. In the present review, approximately $39.42 \%$ of patients had no symptoms, although X-ray plain film demonstrated an enlarged cardiac silhouette. Signs of pericardial effusion were also identified during physical examination, including enlarged heart border, distant heart sounds, JVD and edema. JVD and a distant heart sound were only identified in $<50 \%$ of the included cases. Furthermore, 16 cases presented with low voltage in the limb lead upon electrocardiographic examination. Cardiomegaly was easily identified by X-ray screening in $93.27 \%$ of cases.

The diagnosis of chylous pericardium relied upon the pericardial fluid analysis. Regarding the appearance of the fluid, a milky white pericardial effusion (78 cases, $72.89 \%$ ) was typically observed, followed by pink or bloody fluid (4 cases, $3.85 \%$ ). The level of TG was tested in 63 cases and was in the range of $181-4299 \mathrm{mg} / \mathrm{dl}$, with a median of $1305.43 \pm 865.34 \mathrm{mg} / \mathrm{dl}$, while the TC level was tested in 42 cases and was within the range of $42-1021 \mathrm{mg} / \mathrm{dl}$, with a mean value of $132.42 \pm 148.22 \mathrm{mg} / \mathrm{dl}$. The $\mathrm{TC} / \mathrm{TG}$ ratio in all $\mathrm{CP}$ patients included in the current study was $<1$.

Imaging served an important role in the exploration of the leak site of CP, as shown in Table II. In total, 42 (40.38\%) cases underwent lymphangioscintigraphy and 24 of these cases presented abnormal accumulation within the pericardial sac. In addition, 24 cases (23.07\%) underwent lymphangiography and 18 of them had abnormal finding; 35 (33.65\%) cases underwent chest contrast-enhanced computed tomography (CT) scanning without any secondary disease finding.

Of the 104 identified cases, treatment information was provided for 102 patients. A total of 62 cases were subjected to initial conservative management, including dietary control involving total parenteral nutrition (TPN), low-fat diet and MCT diet. Among these patients, 36 cases did not improve and underwent subsequent surgery, while 26 cases were successfully treated following conservative management. In total, 71 cases $(71.2 \%)$ were treated by surgery. Formation of a pericardial window was used in 50 cases $(48.08 \%)$ and ligation of the thoracic duct was performed in 46 cases (44.23\%). There were also 4 cases $(3.85 \%)$ that received embolization. Embolization of the thoracic duct was an uncommon type of surgery for $\mathrm{CP}$, which was performed in weak patients or subsequent to failure of ligation. Furthermore, pericardioperitoneal shunt was conducted in 3 cases $(3.88 \%)$. Only 1 case underwent reconstruction of the thoracic duct, which is rarely performed.

Follow-up data were recorded in 64 cases, with a median follow-up time of 12 months (1 month to 9 years) and all patients had a positive outcome. Only 1 case was complicated by constrictive pericarditis. No patients succumbed to the condition during the follow-up period.

A scoring system has been suggested by Dib et al (6) to assist in establishing the diagnosis of CP. The score is calculated according to the following features: i) Milky yellowish appearance of fluid; ii) TG level of $>500 \mathrm{mg} / \mathrm{dl}$; iii) $\mathrm{TC} / \mathrm{TG}$
Table I. Clinical data of 104 chylopericardium cases identified in the literature.

\begin{tabular}{lcc}
\hline Characteristics & $\begin{array}{c}\text { Number of } \\
\text { cases (n) }\end{array}$ & $\begin{array}{c}\text { Percentage } \\
(\%)\end{array}$ \\
\hline Symptom & & \\
Asymptomatic & 41 & 39.42 \\
Dyspnea & 48 & 53.90 \\
Coughing & 11 & 10.58 \\
Palpitation & 10 & 9.62 \\
Cardiac tamponade & 7 & 6.73 \\
Chest pain & 4 & 3.85 \\
GI symptoms & 4 & 3.85 \\
Syncope & 3 & 3.40 \\
Fatigue & 3 & 2.88 \\
Edema & 2 & 1.92 \\
Physical examination & & \\
JVD & 23 & 32.69 \\
Distant heart sound & 34 & \\
Electrocardiogram & & \\
Low voltage in limb lead & 16 & \\
X-ray scanning & & \\
Cardiomegaly & 97 & \\
\hline GI, gastrointestinal; JVD, jugular venous distention. & \\
\hline
\end{tabular}

Table II. Imaging data.

\begin{tabular}{lccc}
\hline Type of imaging & $\begin{array}{c}\text { Number of } \\
\text { cases (n) }\end{array}$ & $\begin{array}{c}\text { Percentage } \\
(\%)\end{array}$ & $\begin{array}{c}\text { Abnormal } \\
\text { finding (n) }\end{array}$ \\
\hline Chest X-ray & 97 & 93.27 & 97 \\
Echocardiography & 79 & 75.96 & 79 \\
Lymphangioscintigraphy & 42 & 40.38 & 24 \\
Lymphangiography & 24 & 23.07 & 18 \\
Computed tomography & 35 & 33.65 & 0 \\
\hline
\end{tabular}

ratio of $<1$; and iv) negative fluid bacterial culture and lymphocytic predominance on fluid cell count. Each feature is given 1 point, and a score of 2 (specificity and sensitivity of 100\%) is required for the diagnosis of $\mathrm{CP}(6)$. The patient in the current study had a score of 4 , which could be confirmed as CP.

Other conditions that may mimic a chylous pericardium include cholesterol pericarditis $(88,89)$ and purulent pericarditis $(90,91)$, which can be complicated by a pericardial effusion with a positive chylous test. The pericardial effusion in cholesterol pericarditis typically appears orange and full of cholesterol crystals. Clinically, patients with purulent pericarditis typically have more severe presentation compared with patients with CP. Diagnosis of pericardial effusion secondary to cholesterol and purulent pericarditis depends on the cell count, biochemistry, cytology and fluid culture findings.

Echocardiography is helpful in diagnosing pericardial effusion and helps guide pericardiocentesis. Enlarged 
cardiac silhouette is often observed on chest X-ray scans in patients with CP (14). The main diagnostic methods for CP include lymphoscintigraphy and lymphangiography. However, diagnosis is highly variable depending on the device and technique. Lymphangiography is performed to assess the thoracic duct anatomy by administering a contrast agent directly into catheterized lymph vessels (20). When successful, this test is able to demonstrate the connection between the pericardial capacity and lymphatic system. However, lymphangiography is invasive and requires insertion of a catheter into a lymphatic vessel and use of a contrast agent. Combining lymphangiography and CT has also been reported to be useful for detecting lymphatic vessels and abnormal communications within the pericardial space (92). Lymphoscintigraphy is a noninvasive alternative to lymphangiography, which utilizes radionuclides as imaging agents and can be performed using oral or subcutaneous administration of radiotracers (93). Chest CT scanning is also helpful to detect the association between the thoracic duct and surrounding organs (94).

Regardless of the etiology of $\mathrm{CP}$, conservative therapy in the absence of hemodynamic compromise is the first line treatment. MCT diet or TPN can also be attempted; however, the majority of patients will require pericardiocentesis for symptom alleviation (95). Pericardiocentesis followed by drainage and MCT diet should be considered as a primary management strategy since the mortality rate of $\mathrm{CP}$ is not high (6). Definitive treatment with surgery is recommended in cases where the daily pericardial drainage is at $>1,500 \mathrm{ml} / \mathrm{day}$, drainage does not decrease after 5 days (>500 $\mathrm{ml} /$ day) or malnutrition occurs (96). Management with pericardiocentesis alone rarely prevents recurrence. Pericardiocentesis followed by pericardiostomy s another reasonable approach, particularly when the patient is reluctant to undergo surgery or has a concomitant life-limiting disease. Conservative treatment failed in $57.1 \%$ of the cases as reported previously (1), and in $58.06 \%$ of cases as reported in the present study. However, surgical treatment was curative in all cases. For patients presenting a recurrent chylous pericardial effusion within 3-month, surgical treatment is recommended.

There are different approaches for the surgical treatment of CP (6). Pericardiectomy is performed to ensure complete drainage and to prevent secondary constrictive pericarditis. Creation of a pericardial window alone is insufficient since it has a high recurrence rate, as it does not close the communication between the thoracic duct and the pericardial sac (11). Ligation of the thoracic duct above the level of the diaphragm is the best choice and is recommended by the majority of surgeons (81). Video-assisted thoracoscopic surgery is also becoming more favorable by cardiothoracic surgeons since it is less invasive and affects the pulmonary function to a lesser extent. Furthermore, embolism of the thoracic duct is used in certain situation, and is an alternative type of surgery, particularly for patients who refuse to be subjected or re-subjected to more invasive surgery, or those that cannot tolerate anesthetization (10). Another novel surgical therapy is the reconstruction of the occluded thoracic duct (97). This approach is most consistent with the restoration of nearly normal physiology. Although thoracic duct reconstruction results in substantial symptomatic improvement and volume reduction, CP may recur. Recurrences should be managed conservatively since full restoration of the normal lymphatic flow may require a certain time.

The patient in the present case study underwent thoracic duct reconstruction surgery and required several months for complete restoration. However, the short term and long term prognosis of this patient was good. Based on the literature review conducted, the current case is the first reported case of primary $\mathrm{CP}$ that underwent lymphatic reconstructive surgery and had a 7-year follow up. This case aims to provide further insight on this condition to assist in the treatment of primary CP.

In conclusion, the present study reported the case of a 57-year-old Chinese male who presented with nonspecific symptoms of primary $\mathrm{CP}$, which is a rare condition with only $\sim 100$ cases reported worldwide to date. The current patient underwent a rare type of surgery of the thoracic duct, namely left internal jugular vein anastomosis, which was only reported by Melduni et al from the Mayo clinic in 2008 (97). In addition, long-term follow-up findings subsequent to thoracic duct anastomosis surgery were reported for the present patient. A systematic literature review was also performed, analyzing the etiology, symptoms, physical examination findings, laboratory results, imaging, type of surgery and follow-up data of primary $\mathrm{CP}$. A relative large number of cases reported during the past 60 years were included in this systematic review. Correct diagnosis can be achieved with analysis of the pericardial effusion, while lymphoscintigraphy and lymphangiography are useful for locating the chyle leak site. Surgical management is the most successful treatment and is associated with a favorable prognosis. The current study provided an overall perspective on the etiology, symptoms, physical examination and laboratory findings, imaging, type of surgery and follow-up data of primary $\mathrm{CP}$, and this evidence will assist in improving the understanding and recognition of this rare disease.

\section{References}

1. Hasebroek K: Analyse einer chylösen pericardialen Flüssigkeit (Chylopericardium). Biol Chem 12: 289-294, 1888 (In German).

2. Groves LK and Effler DB: Primary chylopericardium. N Engl J Med 250: 520-523, 1954.

3. Raza M and Matar K: Idiopathic chylothorax and chylopericardium resistant to conservative and surgical management. Heart Lung Circ 18: 229-232, 2009.

4. Courtney M and Ayyagari RR: Idiopathic chylopericardium treated by percutaneous thoracic duct embolization after failed surgical thoracic duct ligation. Pediatr Radiol 45: 927-930, 2015.

5. Ossiani MH, McCauley RG and Patel HT: Primary idiopathic chylopericardium. Pediatr Radiol 33: 357-359, 2003.

6. Dib C, Tajik AJ, Park S, Kheir ME, Khandieria B and Mookadam F: Chylopericardium in adults: A literature review over the past decade (1996-2006). J Thorac Cardiovasc Surg 136: 650-656, 2008

7. Faul JL, Berry GJ, Colby TV, Ruoss SJ, Walter MB, Rosen GD and Raffin TA: Thoracic lymphangiomas, lymphangiectasis, lymphangiomatosis, and lymphatic dysplasia syndrome. Am J Respir Crit Care Med 161: 1037-1046, 2000.

8. Rostom AY: Treatment of thoracic lymphangiomatosis. Arch Dis Child 83: 138-139, 2000.

9. Luisada AA: Development and structure of the cardiovascular system. Am Heart J 64: 435, 1962.

10. Chen E and Itkin M: Thoracic duct embolization for chylous leaks. Semin Intervent Radiol 28: 63-74, 2011.

11. Dunn RP: Primary chylopericardium: A review of the literature and an illustrated case. Am Heart J 89: 369-377, 1975.

12. Naef AP: Primary chylopericardium and its surgical treatment. Dis Chest 30: 160-167, 1956. 
13. Svedjeholm R, Jansson K and Olin C: Primary idiopathic chylopericardium-a case report and review of the literature. Eur J Cardiothorac Surg 11: 387-390, 1997.

14. Harada K, Takigawa I, Toyoda H, Okada T and Usami H: Primary chylopericardium recovered without surgical treatment. Report of a case and review of the literature. Jpn Circ J 46: 162-171, 1982.

15. Akamatsu H, Amano J, Sakamoto T and Suzuki A: Primary chylopericardium. Ann Thorac Surg 58: 262-266, 1994.

16. Han Z, Li S, Jing H and Liu H: Primary idiopathic chylopericardium: A retrospective case series. BMC Surg 15: 61, 2015.

17. Yankopoulos NA, Akbarian M, Starkey GW and Abelmann WH: Isolated chylopericardium. Diagnosis, hemodynamic studies and surgical treatment. Am J Cardiol 19: 440-446, 1967.

18. Fawal IA, Kirkland L, Dykes R and Foster GL: Chronic primary chylopericardium. Report of a case and review of the literature. Circulation 35: 777-782, 1967.

19. Puig-Massana M, Murtra M and Calbet JM: Idiopathic massive chylopericardium. Br Heart J 34: 431-433, 1972.

20. Chavez CM, Rodriquez GR and Conn JH: Isolated chylopericardium. Lymphographic findings and surgical treatment. Am J Cardiol 32: 352-355, 1973.

21. Gallant TE, Hunziker RJ and Gibson TC: Primary chylopericardium: The role of lymphangiography. AJR Am J Roentgenol 129: 1043-1045, 1977.

22. Charnilas Y, Levo Y, Weiss A, Glaser J and Levy MJ: Isolated idiopathic chylopericardium. J Thorac Cardiovasc Surg 73: 719-721, 1977.

23. Toltzis RJ, Rosenthal A, Fellows K, Castaneda AR and Nadas AS: Chylous reflux syndrome involving the pericardium and lung. Chest 74: 457-458, 1978.

24. de Haan HP, Kolff $\mathbf{J}$ and Buis B: Isolated chylopericardium due to lymphangiomatous dysplasia of the thymus. Eur Heart J 5: 846-849, 1984

25. Mask WK, Penido JR and Printup C: Primary idiopathic chylopericardium. J Thorac Cardiovase Surg 99: 569-571, 1990.

26. Itoh $T$, Tanaka $S$, Nakanishi $M$, Nishiyama K, Kitajima $N$, Kinoshita Y, Inatome T, Inoh T and Fukuzaki H: Primary chylopericardium with pulmonary shadow and large granular lymphocytosis: A case report. Lymphology 24: 168-173, 1991.

27. de Winter RJ, Bresser P, Romer JW, Kromhout JG and Reekers J: Idiopathic chylopericardium with bilateral pulmonary reflux of chyle. Am Heart J 127: 936-939, 1994.

28. Scholten C, Staudacher M, Girsch W, Wolf G, Grimm M, Binder T, Lang I and Stefenelli T: A novel therapeutic strategy for the management of idiopathic chylopericardium and chylothorax. Surgery 123: 369-370, 1998.

29. Mewis C, Kühlkamp V, Sokiranski R and Karsch KR: Primary chylopericardium due to partial aplasia of the thoracic duct. Eur Heart J 18: 880-881, 1997.

30. Baratella MC, Montesello M and Marinato P: Images in cardiology. Idiopathic chylopericardium. Heart 80: 376, 1998.

31. Wang CH, Yen TC, Ng KK, Lee CM, Hung MJ and Cherng WJ: Pedal $(99 \mathrm{~m}) \mathrm{Tc}$-sulfur colloid lymphoscintigraphy in primary isolated chylopericardium. Chest 117: 598-601, 2000.

32. Sakata S, Yoshida I, Otani Y, Ishikawa S and Morishita Y: Thoracoscopic treatment of primary chylopericardium. Ann Thorac Surg 69: 1581-1582, 2000.

33. Rizzello V, Colizzi C and Falappa P: Primary chylopericardium due to lymphangiectasias: The crucial role of lymphangiography. Eur Heart J 29: 1974, 2008.

34. Cho BC, Kang SM, Lee SC, Moon JG, Lee DH and Lim SH: Primary idiopathic chylopericardium associated with cervicomediastinal cystic hygroma. Yonsei Med J 46: 439-444, 2005.

35. Mitsui K, Namiki K, Matsumoto H, Konno F, Yoshida R and Miura S: Thoracoscopic treatment for primary chylopericardium: Report of a case. Surg Today 35: 76-79, 2005.

36. Miyoshi K, Nakagawa T, Kokado Y, Matsuoka T, Kameyama K and Okumura N: Primary chylopericardium with pulmonary lymphedema. Thorac Cardiovasc Surg 56: 306-308, 2008.

37. Schild HH, Simon B, Kuhl CK, Nelles M, Koerfer R, Skowasch D, Kuntz-Hehner S and Haude M: Percutaneous treatment of idiopathic chylopericardium. J Vasc Interv Radiol 20: 842-846, 2009.

38. Itkin M, Swe NM, Shapiro SE and Shrager JB: Spontaneous chylopericardium: Delineation of the underlying anatomic pathology by CT lymphangiography. Ann Thorac Surg 87: 1595-1597, 2009.

39. Madison WM Jr and Logue B: Isolated (primary) chylopericardium due to anomalous communications with the thoracic duct, of unknown causation. Am J Med 22: 825-830, 1957.
40. Glasser SP, Cheitlin MD, Serfas LS and Sbar SS: Isolated massive chylopericardium. Am Heart J 75: 663-672, 1968.

41. Lee CY, Di Loreto PC and Kim S: Isolated primary chylopericardium in pregnancy. Obstet Gynecol 43: 586-591, 1974.

42. Jenner R and Oo H: Isolated chylopericardium due to mediastinal lymphangiomatous hamartoma. Thorax 30: 113-117, 1975.

43. Savran SV, Ratshin RA, Shirley JH, Naguwa SM and Goodman L: Idiopathic chylopericardium: 131-I-triolein scan for noninvasive diagnosis. Ann Intern Med 82: 663-665, 1975.

44. Ross P, Joseph S and Walker D: A case of isolated primary chylopericardium. Br Heart J 41: 508-511, 1979.

45. Rankin RN, Raval B and Finley R: Primary chylopericardium: Combined lymphangiographic and CT diagnosis. J Comput Assist Tomogr 4: 869-870, 1980.

46. Torrington KG and Youkey JR: Simultaneous idiopathic chylopericardium and chylothorax. South Med J 74: 357-359, 1981.

47. Bewick DJ, Johnstone DE and Landrigan PL: Primary chylopericardium associated with allergic alveolitis. Can Med Assoc J 130: 1577-1579, 1984.

48. Morishita Y, Taira A, Furoi A, Arima S and Tanaka H: Constrictive pericarditis secondary to primary chylopericardium. Am Heart J 109: 373-375, 1985.

49. Musemeche CA, Riveron FA, Backer CL, Zales VR and Idriss FS: Massive primary chylopericardium: A case report. J Pediatr Surg 25: 840-842, 1990.

50. Yoon YS, Shim WH, Chung TS and Lee YS: Primary idiopathic chylopericardium: Report of a case and review of the literature. Yonsei Med J 34: 98-108, 1993.

51. Chiu CH, Su WJ, Chang JP and Chang CH: Primary chylopericardium: Report of a case. J Formos Med Assoc 92: 468-471, 1993.

52. Taggart SC, Roberts TE and Marshall DA: Chylopericardium complicating pericardiocentesis for acute idiopathic pericardial effusion. J Thorac Cardiovasc Surg 108: 388-389, 1994.

53. Yang MF, Long MQ, Tian J and Li ZJ: A case of chylopericardium diagnosed by lymphoscintigraphy. Zhonghua Heyixue Zazhi 14: 157-158, 1994 (In Chinese).

54. Furrer M, Hopf M and Ris HB: Isolated primary chylopericardium: Treatment by thoracoscopic thoracic duct ligation and pericardial fenestration. J Thorac Cardiovasc Surg 112: 1120-1121, 1996.

55. Chinushi M, Watanabe Y, Aizawa Y, Hanawa H, Yamazoe M, Osman Y, Shibata A and Shinonaga M: Suppression of fluid accumulation following pericardial inflammation in a patient with primary chylopericardium. Jpn Heart J 37: 271-274, 1996.

56. Dogan R, Demircin M, Sarigül A, Celiker A, Güngen Y and Paşaoglu I: Isolated chylopericardium secondary to intrathymic lymphangiomatous malformation. Pediatr Cardiol 17: 413-415, 1996.

57. Yüksel M, Yildizeli B, Zonüzi F and Batirel HF: Isolated primary chylopericardium. Eur J Cardiothorac Surg 12: 319-321, 1997.

58. Akashi H, Tayama K, Ishihara K, Tanaka A, Fujino T, Okazaki T and Aoyagi S: Isolated primary chylopericardium. Jpn Circ J 63: 59-60, 1999.

59. López-Castilla JD, Soult JA, Falcón JM, Muñoz M, Santos J, Gavilan JL and Rodríguez A: Primary idiopathic chylopericardium in a 2 month old successfully treated without surgery. J Pediatr Surg 35: 646-648, 2000.

60. Bhat P, Ananthakrishna R, Panneerselvam A, Yalagudri SD, Rao PS and Nanjappa MC: Recurrent chylopericardium. BMJ Case Rep 2011: pii: bcr0720114520, 2011.

61. Sleilaty G, Rassi I, Alawi A and Jebara VA: Primary isolated chronic chylopericardium. Interact Cardiovasc Thorac Surg 1: 86-87, 2002.

62. Anil SR, Manoj P, Hejmadi A and Kumar RK: Massive primary chylopericardium in an infant. Indian Heart J 54: 295-296, 2002.

63. Watanabe S, Kariatsumari K, Sakasegawa K, Imagama I, Yotsumoto G and Sakata R: Primary chylopericardium treated with video-assisted thoracoscopic surgery. Thorac Cardiovasc Surg 50: 360-361, 2002.

64. Mahon NG, Nölke L, McCann H, Sugrue D and Hurley J: Isolated chylopericardium. Surgeon 1: 236-238, 2003.

65. Fan SH, Ge MJ, Xiang XY and Wang B: Primary chylopericardium: A case report. Zhonguo Xiongxinxueguan Waike Linchuang Zachi 17: 352, 2010 (In Chinese).

66. Nanjo S, Yamazaki J, Tsubuku M, Ohyama T, Ohtsuka T and Nakano H: Primary idiopathic chylopericardium: Report of two cases. Ann Nucl Med 18: 537-539, 2004.

67. Yokusoglu M, Savasoz BS, Baysan O, Erinc K, Gunay C and Isik E: Primary chylopericardium. Thorac Cardiovasc Surg 53: 386-388, 2005. 
68. Zisis C, Rontogianni D, Charalambous E and Bellenis I: Lymphangiomatous hamartoma: Cause or bystander of the isolated chylopericardium? J Thorac Cardiovasc Surg 130: 1201-1202, 2005.

69. Mehrotra S, Peeran NA and Bandyopadhyay A: Idiopathic chylopericardium: An unusual cause of cardiac tamponade. Tex Heart Inst J 33: 249-252, 2006.

70. Cui FH, Xie MY and Huang JP: A primary chylopericardium misdiagnosed as tuberculous pericarditis. Zhongguo Wuzhenxue Zazhi 9: 1825-1826, 2006 (In Chinese).

71. Cervantes-Salazar JL, Calderón-Colmenero JE and Ramírez-Marroquín S: Idiopathic chylopericardium. A case in point. Rev Esp Cardiol 60: 884-885, 2007 (In Spanish)

72. Silva MA, Martins AS, Campos NL, Andrade RR, Tohi LM and Hueb JC: Primary idiopathic chylopericardium-case report. Arq Bras Cardiol 92: e40-e43, e67-e70, 2009 (In English, Multiple languages)

73. Timóteo AT, Albino JP, Branco LM, Banazol N, Colarinha P, Jalles NT and Ferreira R: Primary idiopathic chylopericardium. Rev Port Cardiol 28: 325-332, 2009 (In English, Portuguese).

74. Barbetakis N, Asteriou C, Konstantinou D, Giannoglou D, Tsilikas C and Giannoglou G: Spontaneous chylous cardiac tamponade: A case report. J Cardiothorac Surg 5: 11, 2010.

75. Luaces M, Perales I, Núñez-Gil IJ and Cabezudo J: Non-invasive diagnosis of chylopericardium by cardiac magnetic resonance imaging. Eur Heart J 31: 823, 2010.

76. Novitzky D and Guglin M: Chylopericardium presenting with tamponade and cardiogenic shock. J Card Surg 25: 522-524, 2010.

77. Tan JX, Fu Y and Chen J: Primary idiopathic chylopericardium: A case report. Cardiol Young 23: 773-775, 2013

78. Mandarry MT, Ru XH, Wei ZQ and Ge MJ: Primary idiopathic chylopericardium: A rare case with a synopsis of the literature. Singapore Med J 53: e156-e158, 2012.

79. Gilmore D and Colson YL: Recurrent chylous pericardial effusion and left neck mass. Thorac Cardiovasc Surg 60 (Suppl 2): e25-e27, 2012

80. Kwon JB, Choi SY, Kim CK and Park CB: Primary idiopathic silent chylopericardium. J Cardiothorac Surg 8: 28, 2013.

81. Rivera-Beltrán S, Ortíz VN, Díaz R and Hernández JA: Transabdominal ligation of the thoracic duct with pericardial-peritoneal shunting in a case of primary idiopathic chylous pericardial effusion. J Pediatr Surg 48: 1434-1437, 2013.

82. Rosa GM, Campisi C, Bioccardo F, Dorighi U, Parodi A, Molinari L, Spinaci S, Dessalvi S, Brunelli C and Campisi C: Chylopericardium: A case report demonstrating utility of lymphography combined with 3D computed tomography for corrective surgical treatment using VATS. Lymphology 47: 40-43, 2014

83. Vinayakumar D, Arunkumar G, Sajeev CG, Rajesh G, Muneer K, Haridasan V, Babu K and Krishnan MN: Cystic lymphangioma of pericardium presenting as isolated chylopericardium-a case report. Indian Heart J 66: 119-121, 2014.
84. Karakurt C, Celik SF, Celik RM, Elkiran O, Ulutas H and Kuzucu A: Primary idiopathic chylopericardium presenting with cardiac tamponade. Herz 39: 644-646, 2014.

85. Chew H, Shetty P, Elahi M and Akhunji Z: A case of spontaneous chylous pericardial effusion in Poland syndrome. Gen Thorac Cardiovasc Surg 62: 386-389, 2014.

86. Huang JW, Zhao D, Han F, Qi BL, Zhang SQ, Liu GT and Lin Y: A primary idiopathic chylopericardium. Zhongguo Yaowu Jingjixue 10: 255-256, 2014 (In Chinese).

87. Atkinson $\mathrm{C}$ and Banks K: Imaging idiopathic chylopericardium with 99mTc-SC lymphoscintigraphy and SPECT/CT. Clin Nucl Med 40: e508-e510, 2015.

88. Fernandes F, Vieira GS, Arteaga E, Ianni BM, Pêgo- Fernandes P and Mady C: Cholesterol pericarditis. A specific but rare cause of pericardial disease. Arq Bras Cardiol 76: 391-394, 2001.

89. Alsemgeest F, Spiegelenberg SR and Kamp O: Cholesterol pericarditis with massive pericardial cholesterol cyst. Eur Heart J 33: 1554,2012

90. Cilloniz C, Rangel E, Barlascini C, Piroddi IM, Torres A and Nicolini A: Streptococcus pneumoniae-associated pneumonia complicated by purulent pericarditis: Case series. J Bras Pneumol 41: 389-394, 2015 (In English, Portuguese).

91. Sagristà-Sauleda J, Barrabés JA, Permanyer-Miralda G and Soler-Soler J: Purulent pericarditis: Review of a 20-year experience in a general hospital. J Am Coll Cardiol 22: 1661-1665, 1993.

92. Liu DY, Shao Y and Shi JX: Unilateral pedal lymphangiography with non-contrast computerized tomography is valuable in the location and treatment decision of idiopathic chylothorax. J Cardiothorac Surg 9: 8, 2014.

93. Chen FC, Huang JL, Lin WY and Ting CT: Pedal Tc-99m phytate lymphoscintigraphy in primary chylopericardium. Int J Cardiol 90: 341-343, 2003.

94. Sachs PB, Zelch MG, Rice TW, Geisinger MA, Risius B and Lammert GK: Diagnosis and localization of laceration of the thoracic duct: Usefulness of lymphangiography and CT. AJR Am J Roentgenol 157: 703-705, 1991.

95. Pitol R, Pederiva JR, Pasin F and Vitola D: Isolated chylopericardium after cardiac surgery. Arq Bras Cardiol 82: 384-389, 2004 (In English, Portuguese). Denfield SW, Rodriguez A, Miller-Hance WC, Stein F, Ott DA, Jefferson LS and Bricker JT: Management of postoperative chylopericardium in childhood. Am J Cardiol 63: 1416-1418, 1989.

96. Selle JG, Snyder WH III and Schreiber JT: Chylothorax: Indications for surgery. Ann Surg 177: 245-249, 1973.

97. Melduni RM, Oh JK, Bunch TJ, Sinak LJ and Gloviczki P Reconstruction of occluded thoracic duct for treatment of chylopericardium: A novel surgical therapy. J Vasc Surg 48: 1600-1602, 2008. 